\title{
The Need of Analysis on the Assessment Model of Speaking Ability Based on Information Technology
}

\author{
Hari Wahyono ${ }^{1}$, Rustono ${ }^{1}$, Sukarno $^{2}$, Mimi Mulyani ${ }^{1}$ \\ ${ }^{1}$ Graduate School, Universitas Negeri Semarang, Indonesia \\ ${ }^{2}$ Universitas Tidar, Indonesia \\ Email:wahyono@gmail.com
}

\begin{abstract}
The method used in this research was Research and Development (R\&D) method. R\&D research is conducted through three main stages: (1) preliminary study, (2) model development, and (3) model effectiveness test. Preliminary study of assessment model development of students' speaking ability based on information technology involves observation and questionnaire analysis. The respondents of this research were lecturer of speaking ability subject and students of Indonesian Language and Literature Education Study Program. The results of the observation and analysis of the respondents showed that (1) $85.55 \%$ stated that assessment condition of speaking competence test is currently still using manual way; (2) manual assessment has many weaknesses, and it still does not fulfill assessment principles completely; (3) 86.66\% respondents expected more innovative assessment model, which is the assessment utilizing information technology; (4) the result of assessment model facilitates assessment process and the result is objective; (5) the respondents suggested the researchers to develop assessment model utilizing information technology. To fulfill their demand and suggestion, the researchers develop an assessment model which is based on information technology. The assessment model is in the form of software of assessment system that can be accessed on website. Users can access through www.mutiaraberisi.com.
\end{abstract}

Key words: need of analysis, speaking assessment model, information technology

\section{Introduction}

Speaking is a basis of communication form that differs human as a species from the others. Arsyad and Mukti (1988) argue that speaking skill is an ability to produce sounds, articulation, or words to express, state and share ideas and feeling. In daily basis, speaking activity is one of communication forms that holds dominant frequency used by human in communication than others. Each person produces eighteen thousand words each day in average (King, 2002). Besides, King (2002) suggests that everyone needs to improve his/her speaking proficiency to be a good speaker. Most people are able to speak, but not all people can do it well and effectively (Chandra, 2002).

Furthermore, the development of speaking skill needs to be improved and assessed. However, the assessment of speaking skill is not good enough especially in terms of the assessors and the one who is assessed. This factor supports the writers to conduct a research about developing assessment model of speaking skill. The assessment of students' speaking skill has been done manually., and this manual assessment still has drawbacks.

The disadvantages found are explained as follows. (1) The assessment process is not effective and efficient because it needs preparation in many facilities such as pages of assessment rubric, observation protocol, etc. (2) It needs high concentration to assess. If it lacks concentration, the result will not be maximal. (3) The assessors cannot see the development of students' skills in each aspect that is fully integrated because the assessment results are in different assessment pages. (4) It is difficult to give feedback in detail because there is no recording that is assessed audibly or visually so that there is only spoken feedback which is remembered by the assessors. (5) It requires manual administration if the assessors or students need to know whether the development of speaking skill will be integrated and continued. If the recap is not good, there will be difficulties found in knowing the previous results of the assessment.

Besides, the writers get information about the assessed aspects in speaking skill. Based on interview results, it is found that some lecturers in state university have differences in terms of (1) the components of aspects, (2) the assessed aspects, (3) the detailed aspects for being graded, (4) the indicators, and (5) the scoring. Regarding this information, it can be stated that there is still no similarities or standards of speaking skill assessments among the lecturers of university. 
According to those drawbacks, it can be showed that assessment of speaking skill does not internalize assessments principle yet. The principles of assessment are based on the Regulation of Education Ministry of the Republic of Indonesia Number 20, 2007 about Standard of Educational Assessment. The assessment principles comprise several points: (1) valid, (2) objective, (3) same, (4) integrated, (5) economic, (6) transparent, (7) meaningful, (8) educated, (9) fully continued, and (10) accountable.

Those assessment needs to be done thoroughly and continuously. Full assessment means that all aspects scored must cover all measured aspects.

The previous studies used in this research are relevant to this research topic. The previous studies were taken from Gomez (1994), Hughes (2009), Halijah (2010), Wöllmer (2011), Christianson (2012), Hasyim (2012), Astriani (2014), Rahmawati (2014), Wei (2015), Rudhiani (2015), Mujimim (2016), and Hilaliyah (2017). The previous researches were used to find the gap as well as the difference so that this research does not reiterate the previous ones.

The research concerns on developing speaking skill assessment through information and technology. The findings were different with the previous studies. The aim of this research is to produce a model of speaking skill assessment based on information and technology. The product of this research is expected to solve the drawbacks in assessment model used before this research is carried out.

\section{Methods}

This research used research and development method. This research employed research and development approach proposed by Borg \& Gall, (1989). The orientation of this research focused on the development of a product in which development process was described carefully, and the obtained product was evaluated. The expected result of this research is an assessment model in the form of software of speaking ability assessment system.

Respondent of this study were students and lecturers of Indonesian Language Education and Literature Program, Faculty of Teacher Training and Education, Universitas Tidar. It was expected that the respondents might provide depiction or information on speaking ability assessment model used currently by the lecturers. The obtained information was then used as research follow-up basis. Besides, respondents also provided their wishes, hopes, and suggestions related to the assessment model of speaking ability.

First phase of this research was collecting previous researches and information, which was preliminary study for collecting information by conducting field observation of previous research studies and theoretical studies. Field observation was conducted to acquire assessment condition currently used. Previous research studies were used to acquire information on relevant researches which have been conducted and to provide a road map of research. In addition, theoretical studies were used to acquire relevant theories to be applied as theoretical base of this research.

In order to obtain observation results, questionnaires were used and distributed to the respondents involving 90 students as well as 4 lecturers teaching speaking ability subject. Both local research journals and international research journals were explored in order to acquire information on previous relevant research results to the current research. Various reference books especially the ones related to speaking, assessment, as well as research and development were explored in order to acquire relevant theories for this research.

\section{Results and Discussion}

The obtained research results include (1) analysis of students and lecturers' need for information technology-based speaking assessment model and (2) characteristics of information technology-based speaking assessment model. The questionnaires were taken from lecturers and students of Indonesian Language Education and Literature Program. The questionnaire data was classified into two categories: the one taken from students' perceptions and the other one based on lecturers'.

Based on the questionnaire analysis, it shows that $85.55 \%$ of the students stated that assessment of speaking ability was still carried out manually. $14.55 \%$ of the students stated that the mixed assessment was used. The students expected that speaking ability assessment could be applied more objectively by utilizing the information technology. With regard to this condition, all of the students stated that the assessment was done in a mixed system, in which combination between the tests and non- 
test assessment was used. Regarding the assessment model desired by students, $644.4 \%$ of the students stated that information technology or digital-based assessment was indispensable while $24.44 \%$ of them stated that was necessary. Based on the data, it can also be seen that all of the students need an information technology-based speaking assessment model.

Related with the desired model, it was found that Ms. Excel and web-based applications are considered appropriate software for speaking assessment model based on information technology in which they can be simply and easily developed as well as appropriately used. While $13.33 \%$ of the students chose Ms. Excel, $86.66 \%$ of the students preferred web-based program. Thus, it can be considered that most of the students expected assessment of speaking ability was carried out by using web/page.

The second indicator analyzed was the need of speaking skills evaluation model based on the assessment criteria used. Regarding the question of what should be contained in the information technology-based speaking assessment model, the answer in the form of assessment component becomes the desirable one by $46.04 \%$ of the total respondents. Besides, $50 \%$ of the respondents stated speaking assessment aspects should contain three elements: verbal aspects, non-verbal aspects, and content/ ideas aspects. Moreover, $71.42 \%$ of the student agreed that there should be clarity regarding the scoring for each aspect category.

It was expected that the respondents could provide suggestion regarding the name or term used for the resulted assessment model. The respondents' answers suggested that the scoring model was named MUTIARA BERISI (Assessing Speaking Quality using Information Technology). It was based on the fact that $67.77 \%$ of the respondents chose that term while $32.22 \%$ of the respondents took the term SIPKB (Information Systems of Speaking Assessment Ability). Regarding the analysis results on the content of speaking ability assessment all respondents stated that things included in the instrument consist of assessment rules, assessment components, assessed aspects, assessed elements, and scoring ranges. Problems of the aspects assessed, according to students' perceptions include verbal or linguistic aspects, content, and non-verbal aspects. Some students came with different perceptions which were supporting aspects and appearance aspects. $21.11 \%$ of the respondents chose supporting aspects while $55.55 \%$ respondents preferred appearance aspect. The expected webpage was www.mutiaraberisi.com.

Regarding the elements assessed, the respondents perceived that linguistic aspects include pronunciation, intonation, pace, pause, and accents. The elements of content consist of the suitability of the content discussed with the assessment topic, the coherence of the content being discussed, and completeness of the contents conveyed. Then, (1) appearance, (2) way of viewing, (3) mimic, (4) gestures/ body language, (5) volume, and (6) way of standing were the elements of non-linguistic aspects. The scoring condition in the assessment lies in the $11^{\text {th }}$ indicator. In this indicator, it was found that $40 \%$ of the students stated the scoring existed while $47.77 \%$ of them argued there was no scoring. $12.22 \%$ of the students stated there was less scoring. It can be said that there was a vagueness of scoring in students' speaking ability assessment. Therefore, the upcoming data deals with whether the scoring issue in every assessed aspect was necessary or unnecessary.

Respondents' answers dealing with the issue of whether the scoring is necessary or unnecessary showed most of students stated scoring was indispensable. $79 \%$ of the students stated scoring was indispensable while $11 \%$ of them stated it was unnecessary. Thus, it indicated that scoring was necessary in each aspect assessed. Dealing with the scoring difference, it was found that scoring for each aspect should be different. $71.11 \%$ of the students chose that the scoring should be different, and $5.55 \%$ of them argued it should be slightly different while $24.44 \%$ of them respondents contended the scoring should not be different.

\section{Conclusion}

Based on the observation results, the results of previous studies, and the analysis results taken from lecturers and students, it can be concluded that generally, assessment of speaking used by the lecturers was still manual model, but some employed information technology, in this case Ms. Excel program.

Furthermore, manual scoring still has disadvantages. There has to be an innovative assessment model for measuring speaking ability which utilizes information technology.

Appropriate research approach used in this research was research and development $(\mathrm{R} \& \mathrm{D})$. The model developed through this 
research is information technology-based students' speaking ability software model. Software may contain audiovisuals such as recordings. The software is served in the form of page or website.

In the end, the respondents suggested terms MUTIARA BERISI (acronym of: Assessing Quality of Speech based on Information Technology) for the outcome of this research.

\section{References}

Arsyad, Maidar G., \& Mukti, U.S. 1988. Pembinaan Kemampuan Berbicara Bahasa Indonesia. Jakarta: Erlangga.

Astriani, Dandan Suprtman, Rahayu Pristiwati. (2014). Pengaruh Kebiasaan Menonton Televisi Acara Informasi dan Pergaulan Teman Sebaya terhadap Keterampilan Berbicara Siswa Kelas VIII MTs NU Ungaran. Jurnal Pendidikan Bahasa dan Sastra Indonesia 3(1). Retrieved from http://journal.unnes.ac.id/sju/index.php/jpbs $\mathrm{i}$

Borg, R Walter., \& Gall Meredith D. 1989. Educational Research: An Introduction. London: Longman, Inc.

Christianson, Mark, Christopher Hoskins. 2009. Evaluating the Effectiveness of a VideoRecording Based Self-Assessment System for Academic Speaking. University Atsuko Watanabe International Christian. Retrieved from

web.icu.ac.jp/lrb/docs/ChristiansonHoskins -Watanabe

Gomez, Pedro, Daniel Martinez, Victor Nieto, Victoria Rodellar. 1994. MECALLSAT. A Multimedia Environment for ComputerAided Language Learning Incorporating Speech Assessment Techniques. Retrieved from http://www.iscaspeech.org/archive/icslp 1994/i94 1295.html.

Halijah, Siti. 2010. Evaluasi Keterampilan Berbicara dalam Pembelajaran Bahasa Indonesia. Jurnal Penelitian. Untan.

Hasyim, Evi. 2011. Model Kemampuan Berbahasa Indonesia Lisan Siswa Sekolah Dasar Berdasarkan Pendekatan Komunikatif. Jurnal FIP UNG.

Hilaliyah. 2017. Tes Keterampilan Berbicara, dalam Pembelajaran. Open Journal System Membaca (Bahasa dan Sastra Indonesia), 2(1). Banten. FKIP Untirta.

King, Larry. 2002. Seni Berbicara kepada Siapa Saja, Kapan Saja, dan di Mana Saja. Jakarta: PT Gramedia Pustaka Utama.

Rahmawati, Laili Etika, Nuraini Fatimah. 2014. Pengembangan Model Penilaian Autentik Kompetensi Berbicara. Jurnal Penelitian Varia Pendidikan, 26(1). Surakarta: Universitas Muhammadiyah Surakarta.

Regulation of Education Ministry of the Republic of Indonesia Number 20, 2007 on Educational Scoring Standard, Jakarta: Direktorat Jenderal Manajemen Pendidikan Dasar dan Menengah.

Rudhiani dan Wagiran. 2015. Rekonstruksi Soal Penilaian Aspek Keterampilan Mata Pelajaran Bahasa Indonesia Kelas X Kurikulum 2013. JPBSI 4 (1) (2015). Jurnal Pendidikan Bahasa dan Sastra Indonesia. Retrieved from http://journal.unnes.ac.id/sju/index.php/jpbs i

Wei dan Lorena Llosa (2015). Language Assessment Quarterly. New York: Routledge Taylor and Francis Group

Wöllmer, Martin, Felix Weninger, Florian Eyben, BjörnSchuller. 2011. Computational Assessment of Interest in Speech-Facing the Real-Life Challenge. Retrieved from http://mediatum.ub.tum.de/doc/1107339/11 07339 